\title{
The Resolving of Political Party's Membership Disputes in Indonesia Democracy System
}

\author{
Iwan Rachmad Soetijono $^{1} \quad$ Widodo Ekatjahjana $^{2} \quad$ Aries Harianto $^{3}$ Jayus ${ }^{3}$ \\ 1.Doctorate Students at Faculty of Law, University of Jember \\ 2.Professor and Lecturer at Faculty of Law, University of Jember \\ 3.Doctor and Lecturer at the faculty of Law, University of Jember
}

\begin{abstract}
In Indonesia, the regulations on political parties have indeed guaranteed the freedom of political parties and limited excessive interference from the government. These restrictions were to guarantee the freedom and role of political parties as one of the institutions needed in carrying out people's sovereignty. One aspect of regulating the freedom of political parties was the resolution of political party disputes independently. The legal arrangements for resolving political party disputes were directed at simplifying litigation procedures and establishing a strong and independent party system. The regulation also aimed to protect the state ideology, democracy, the rule of law, efficiency, legal certainty, national security and the empowerment of political parties.
\end{abstract}

Keywords: political party, disputes, management organization

DOI: $10.7176 / \mathrm{JLPG} / 97-10$

Publication date:May $31^{\text {st }} 2020$

\section{Introduction}

As a democracy ${ }^{1}$, Indonesia has made political parties increasingly important for Indonesian ${ }^{2}$, because a democratic state is indeed built on a party system. Political party is a manifestation of the right on freedom of association which is closely related to freedom of expression and freedom of thought and belief. These rights are a set of means for citizens to participate in governmental arena, as guarantees of rights ${ }^{3}$ is a prerequisite for democracy. Political parties are increasingly recognized as part of the life system of the state, and it can be seen in the provisions of Article 22E Paragraph (3) of the 1945 Constitution of the Republic of Indonesia (UUD NRI) which states that to elect members of the House of Representatives and members at The Regional House of Representatives is a political party itself. In addition, the Article 6A of the 1945 Constitution of the Republic of Indonesia also stipulates that the election of the President and Vice President shall be conducted directly by the people whose candidate pairs are nominated by a political party or a combination of political parties ${ }^{4}$. The provisions in the Article 6A Paragraph (1) of the 1945 Constitution of the Republic of Indonesia; the pair of candidates for President and Vice President are proposed by political parties or a combination of political parties that participate in the general election before the celebration of the general election.

In Indonesia, the life of political parties is characterized by a variety of internal and external disputes. The disputes that have occurred include management disputes at the Partai Kebangkitan Bangsa (PKB), Partai Persatuan Pembangunan (PPP) and Partai Golongan Karya (GOLKAR). In an effort to safeguard party institutions as pillars of democracy from the threat of division due to internal disputes, the Law Number 2 of 2011 concerning the Amendment to Law Number 2 of 2008 concerning Political Parties, regulates the mechanism for resolving internal disputes of political parties. In fact, every political party has an internal institutional mechanism in managing various problems and disputes. All of them are designed to build party's autonomy in handling and solving various problems.

\footnotetext{
${ }^{1}$ In various literary of democracy notions, democracy is meant here as: Democracy is based on the freely-expressed will of the people to determine their own political economy, social and culture systems and their full participation in all aspects of their lives (democracy is based on the desire expressed freely from the people to determine the political system of social economy and culture itself), Cherif Bassiouni, Toward a Universal Declaration on The Basic Principles of Democracy: Cherif Bassiouni, From Principles to Realization, The Inter-Parliamentary Union, Geneva, Switzerland, 1998, p. 5

${ }^{2}$ Harold J. Laski, A Grammar of Politics, Eleventh Impression, London, George Allen \& Unwin Ltd, 1951, p.312

${ }^{3}$ In a variety of literatures, the definition of rights has varied; the rights referred to here are: it requires a framework of other rights to make this basic political right effective. This is the familiar right and freedom of expression, association and assembly (if the beginning of democracy is the right of citizens to have an attitude/statement in making decisions that affect their lives, on the basis of equality with others, then that requires a framework other rights to make basic political rights effective, this is a common right and freedom of expression, association and deliberation), David Beetham, Democracry: Key Principle, Institutions and Problems, The Inter-Parliementary Union, Geneva, Switzerland, 1998 , p.22

${ }^{4}$ Further provisions for the general election of President and Vice President are regulated in Act Number 23 of 2003 concerning General Elections of President and Vice President, State Gazette of the Republic of Indonesia Number 93 of 2003, Supplement to the State Gazette of the Republic of Indonesia Number 4311. Currently the applicable provisions are Law Number 42 of 2008 concerning General Elections of President and Vice President. Based on these provisions the nomination of the President and Vice President is carried out through a party mechanism. See Jimly Ashiddiqie, Consolidation of Manuscripts of the 1945 Constitution After the Fourth Amendment, (Jakarta: Yarsif Watapone, 2003), p. 45
} 
On the contrary, the political party's autonomy ${ }^{1}$ as a basic principle of democracy is not infrequently confronted with internal democratic mechanisms. Access to justice among party's members (sometimes) faces a deadlock between the will of the majority or a minority of functionaries in the party's management structure that forces their will against the aspirations of the majority to lead to its disputes and divisions. To anticipate it, the Law Number 2 of 2011 concerning the Amendment of Law Number 2 of 2008 on Political Parties has regulated several mechanisms for resolving internal disputes of political parties; for which in substance, are aimed at encouraging the institutionalization of parties on one side and guaranteeing party's autonomy besides regulating and caring of itself.

The dispute over the management of Partai Kebangkitan Bangsa (PKB) requires institutions outside the party, namely the Supreme Court of the Republic of Indonesia. As stated in the Articles of Association (AD)/bylaws (ART) of the party, the highest mechanism in the resolution of management disputes is the highest party forum, namely the congress or conference, but apparently the forum has not been able to optimally resolve the disputes as mentioned in the party's judicial institution which is known as the Party's Court. Directly speaking, these party institutions are also unable to solve the problems that occur. Another evidence is the fact that the party's conflict in the Partai Golongan Karya (GOLKAR) begins with a management conflict which leads to the occurrence of two national deliberation forums held by two different management groups, namely national deliberation in Bali and national deliberation in Ancol Jakarta.

From the two events, the results are handed over to government agencies, namely the Minister of Law and Human Rights. Then, the Minister issues a Decree of the Minister of Law and Human Rights number M.HM07.AH.11.01 2014, October 28, 2014 concerning Ratification of the Changing of the Central Board's (DPP) Composition of Partai Persatuan Pembangunan (PPP) and the Decree of the Ministry of Law and Human Rights Number M.HH, AH, 11.03-26 March 10, 2015 which requests Agung Laksono to immediately form the management. Finally, the cassation ruling from the Supreme Court is regulated, where the Supreme Court has granted the appeal request submitted by Golkar's house in accordance with regulating a decree No: 490K / TUN / 2015. The Supreme Court overturnes the decision of PT. TUN by adjudicating itself and states back to the PTUN decision. Meanwhile, related to the conflict in PPP party, the Supreme Court decision No: 504K/TUN/2015 has granted mengabulkan kasasi pemohon dan dinyatakan kembali ke putusan PTUN.

This Civil Court of Justice (PTUN) decision is a justification of recognition by the State; in this case the government due to a dispute from the political party. Institutionally, a political party is actually a civil legal entity established by a group of people who have the same ideals and goals, but are functionally public-oriented and become a platform for the struggle for political aspirations in government. For this reason, institutionalization of the party has become very important in creating democratic government stability. A basic capital in building the efficiency and effectiveness of government on the one hand and the accountability and responsiveness of government on the other. In its development, political parties as an organization are always confronted with the ups and downs of disputes which often lead to divisions.

Based on the description above, this study aims to investigate and overview the management disputes and the role of government in the existing disputes. Some discussion variables can be classified into (1) political party management disputes in Indonesia, (2) the settlement of political party management disputes, and (3) the concept of settlement of political party management disputes according to the Indonesian democratic system.

\section{Research Method}

The method used in this study is normative juridical that emphasizes on normative jurisprudence; while in the search for legal materials, this study still adheres to the juridical aspects in the law governing political parties in relation to the registration and settlement of political party management disputes. The problem approach used, namely historical approach, conceptual approach, statute approach, and comparative approach.

\section{Results and Discussion}

\subsection{Disputes Management of Political Parties in Indonesia}

Dispute is often referred to as conflicts Ali Achmat ${ }^{2}$ argues: "a dispute is a conflict between two or more parties originating from different perceptions about an interest or property rights that can have legal consequences". Based on this understanding, some points can be taken into consideration as follows: ${ }^{3}$

\footnotetext{
${ }^{1}$ In various literatures understanding political parties vary, the political parties referred to here are: A number of citizens, wether amounting to a majority or minority of the whole, who are united and actuated by some common impulse of passion, or of interest, adverse to the rights of other citizens, or to the permanent and aggregate interests of the community (a number of citizens, who are the majority or minority of the whole, who are united or driven by encouragement, or the same interests, who do not match the rights of citizens the other, or permanent and total importance, of the people of Madison, 1978: 88 in Moshe Maor, Political Parties and Party Systems, Routlegde II New Fetter Lane, London, 1997, p. 4

${ }^{2}$ Ali Achmat, Pintar Berbahasa, 2003

${ }^{3}$ DY Witanto, Mediation Procedure Law (In Civil Cases in the General Courts and Religious Courts according to PERMA No. 1 of 2008 concerning Mediation Procedures in Courts), Bandung: Alfabeta, 2011. p. 2
} 
(1) The availability of at least two or more parties;

(2) The availability of the same relationship or importance to certain objects;

(3) The availability of disagreement and differences in perception; and

(4) The availability of legal consequences.

According to Miriam Budiardjo as quoted by Jimly Asshiddiqie, the function of political parties comprehensively means: "means of political communication, political socialization, means of political recruitment, and conflict management"1. The function of political parties that is clearly and firmly interrelated with each other, is that how a political party plays an important role in communication within the political process; for example, the objectives of the political party to the public by carrying out political socialization in the form of political education to grow intelligence and awareness of the people to understand the importance of politics in the life of the state, so that the realization of political recruitment is to produce qualified cadres of political parties to become prospective leaders in certain fields of political office. In addition, political parties can become conflict regulators such as having a political strategy to overcome problems related to statehood through political policy. "Therefore, the Political Party is an important pillar of democracy that urgently needs to be reinforced its institutional aspect (the degree of institutionalization) $)^{2}$.

The opportunities to strengthen political parties will be difficult to realize if the mindset (mainstream mindset) of political party's members or cadres is merely to gain power, whereas a power (as expressed by Lord Acton) tends to be corrupt and absolute power becomes absolutely corrupt as well." ${ }^{3}$. For this reason, a paradigm shift is needed in the way of understanding parties and party's activities; that being a political party member does not mean to everything, but being a representative of people ${ }^{4}$.

With all forms of efforts to improve the function of these political parties, the House of Representatives by the approval of the President, legally stipulates Law Number 2 of 2011 concerning the Amendments to Law Number 2 of 2008 on Political Parties as a form of manifestation for institutional reinforcement in increasing the function and role of political parties towards the state and the community as well as to build the integrity of political parties in Indonesia to be more effective and efficient. The Law Number 2 of 2011 concerning Political Parties explains and determine the regulation of political parties, namely:

Article 1

(1) Political Parties are organizations that are national in nature and formed by a group of Indonesian citizens voluntarily on the basis of the common will and ideals to fight for and defend the political interests of members, society, nation and state, and to maintain the integrity of the Unitary State of the Republic of Indonesia based on Pancasila and the Law on the 1945 Constitution of the Republic of Indonesia.

(2) The Articles of Association of Political Parties abbreviated as Articles of Association (AD), are the basic rules of Political Parties.

(3) The Political Parties' Bylaw (ART) abbreviated as Bylaw (ART) (ART), are regulations established as a describing points of the Articles of Association (AD).

(4) Political Education is a process of learning and understanding of the rights, obligations and responsibilities of every citizen in the life of the nation and state.

(5) Political Party Finance is all the rights and obligations of Political Parties that can be valued in the form of money or goods as well as all forms of wealth and these become the responsibility of Political Parties.

(6) Minister is the Minister in-charge of legal and human rights matters.

(7) The Ministry is the Ministry in-charge of legal and human rights matters.

\section{Article 5}

(1) The Articles of Association (AD) and Bylaw (ART) (ART) can be changed according to the dynamics and needs of Political Parties.

(2) Changes to the Statutes and Bylaw (ART) as referred to paragraph (1), are based on the results of the highest political party's decision-making forum.

(3) Changes to the Statutes and Bylaw (ART) as referred to paragraph (1) must be registered with the Ministry no more than 30 (thirty) days from the date the changes occur.

(4) Registration of changes as referred to paragraph (3) includes a notarial deed regarding the amendments to the Statutes and Bylaw (ART).

\section{Article 16}

(1) Members of a Political Party shall be terminated from membership in a Political Party if:

a) Die;

b) Resign in legal writing;

c) Become a member of another political party; or

\footnotetext{
${ }^{1}$ Moh. Mahfud MD, Debate on Constitutional Law Post Constitutional Amendments, Jakarta: ed. 2, PT RajaGrafindo Persada, 2011. p. 59

${ }^{2}$ Ibid., p. 52

${ }^{3}$ Nuruddin Hady, Authority of the Constitutional Court, Jakarta: ed. 1, Workshop Achievement, 2007. p. 28

${ }^{4}$ Jimly Asshiddiqie, Op. Cit., p. 65
} 
d) Violating the Articles of Association (AD) and Bylaw (ART).

(2) The procedure for terminating membership of a Political Party as referred to paragraph (1) is regulated in the Statutes and Bylaw (ART).

(3) In the event that a dismissed member of a Political Party is a member of a representative institution, the dismissal from membership of a Political Party is followed by dismissal from membership in the representative main segment according to statutory regulations.

\section{Article 23}

(1) The change of management of Political Parties at each level is carried out in accordance with the Statutes and Bylaw (ART)

(2) The composition of the management on the results of the change of management in political party at the central level, shall be registered with the Ministry no more than 30 (thirty) days from the formation of the new management.

(3) The new Political Party management structure as referred to paragraph (2) shall be determined by a Ministerial Decree no more than 7 (seven) days from the receipt of the requirements.

\section{Article 32}

(1) Political Party disputes are resolved internally by Political Parties as regulated in the Statutes and Bylaw (ART).

(2) The internal political party disputes as referred to paragraph (1) shall be carried out by a Political Party Court or other designation formed by a Political Party.

(3) The composition of the Political Party Court or other designations as referred to paragraph (2) shall be submitted by the leaders of Political Parties to the Ministry.

(4) The settlement of internal political party disputes as referred to paragraph (2) must be resolved no more than 60 (sixty) days.

(5) The decision of the Political Party Court or other designation is final and it is binding internally in the case of disputes related to the management.

On the other hand, the elucidation of the Article 32 as meant by "political party disputes" includes some points are:

(1) Disputes that relates to management.

(2) The violation on the rights of members in political parties.

(3) Dismissal without clear reason.

(4) An abuse of authority.

(5) Financial liability, and/or;

(6) Objection to political party's decisions

With such authorities, there is no reason to place a dispute resolution mechanism by a Political Party court merely as a complement to the party's internal dispute resolution system, because this mechanism is provided to ensure dispute resolution that puts forward the spirit as stated in the party's statutes/Articles of Association (AD).

\section{Article 33}

(1) In the event that the dispute resolution (as referred to Article 32) is not reached, it shall be carried out through the District Court.

(2) The District Court decisions are first and final decision. It can only be appealed to the Supreme Court.

(3) A case (as referred to paragraph (1)), shall be settled by the District Court with no more than 60 (sixty) days after the case lawsuit is registered in the District Court's administration and by the Supreme Court with no more than 30 (thirty) days after the memory of cassation is registered in the administration of the Supreme Court.

The rights of members of the political parties are not stipulated in a strict and detailed manner either in Law No. 2/2008 or in Law No. 2/2011. The Article 15 paragraph 2 of Law No. 2/2008 states that members of political parties have the right to determine policies and the right to vote and be elected; and that the members of political parties must obey and implement Bylaw (ART) as well as to participate in the activities of political parties as referred to paragraph 3. Every member in the political party is entitled to get the same treatment from the party; obtain information on all party activities and decisions; obtain political guidance, training and education from the party; get protection and defense from the party; issue opinions and submit proposals, suggestions and criticisms; recruited and be chosen. The decision making process is (sometimes) carried out in not transparent and procedural manner.

The problems with the two major political parties in Indonesia, namely Golongan Karya (GOLKAR) and Partai Persatuan Pembangunan (PPP) which face internal political party disputes, such as in the case of disputes that relates to management. These problems have led to the cassation stage, and that the Supreme Court has simultaneously issued an appeal verdict in the case of Golongan Karya (GOLKAR) in law Number $490 \mathrm{~K} / \mathrm{TUN} / 2015$ as well as the appeal decision for the case of Partai Persatuan Pembangunan (PPP) in law Number 504K/TUN/2015, which states that the internal disputes between each political party have been resolved. However, it needs to be re-emphasized that the disputes within the political parties must be straightened out. 
Clearly speaking that as refer to the Article 33 Paragraph (1) on the Political Party, there is an explanation in which if the settlement of disputes within the political party cannot be reached as described in the Article 32, it can be resolved through the District Court. Besides, in the Article 33 paragraph (2), the submission of an appeal to the Supreme Court is clarified by Saldi Isra as follows:

"as regarded in giving an authority to the internal settlement mechanism of the party is still halfhearted. On the other hand, the formulation of the Article 32 states that the decision on the settlement of party's management disputes is final-binding. Besides, the Article 33 Paragraph (1) on the Political Party actually revokes the authority, because the Party Court's decision could be brought to court if a settlement has not been reached. The full authority of political party to settle party's management in the Party's Court is actually cut down by the formulation of the Article 33 paragraph (1) of the Political Party Law. This inconsistency (both the principle of political party's sovereignty and the fellow of political party's law norm), has the potency to acclaim in legal uncertainty that is detrimental to citizens". 1

\subsection{Settlement of Political Party's Management of Disputes}

The sociological viewpoint in the settlement of political party's disputes is the will of the people to obtain justice with state's rules that contain certainty as formulated in the Constitution. In John Locke's idea of state's rules, there is a little elaboration of the Constitution in accordance to the will of the people of justice ${ }^{2}$. In fact, the constitution has an important position for society in the state, especially related to the rights and obligations of the state and society. On the other hand, because the presence of law is corresponded to its social goals, a progressive law is also closed to the sociological jurisprudence of Roscoe Pound that states ${ }^{3}$ :

"... to enable and compile law making, and also interpretation and application of legal rules, to make more accounts, and more intelligent accounts of the social facts upon which the law must proceed and to which it is to be applied ..."

In Indonesia, the pattern of dispute resolution generally applies two systems of dispute resolution, namely by using Court as the adjudication system and arbitration (often known as "litigation"), and using the path outside the Court (non-adjudication). Meanwhile, the adjudicative dispute resolution can be divided into two kinds, namely Public Adjudicative and Private Adjudicative. Public adjudication is carried out through state court institution (formal litigation). In this context, Samuel P. Huntington in his book "Political Order in Changing Societies" has asserted that the development of democracy has increased the political participation of society in the life of the state $^{4}$. For a democratic country, political parties have positions (status) and roles that are very important in every democratic system. Political parties play a strategic liaison role between government processes and citizens. In fact, many people argue that it is the political parties that actually determine democracy; as Schattscheider has said that the political parties created demoracy ${ }^{5}$. Therefore, political parties are very important pillars to strengthen the degree of institutionalization in every democratic political system. In addition, Schattscheider has also strengthened that "modern democracy is unthinkable save in terms of the parties" ${ }^{6}$. That is why political parties are pillars of democracy, because democracy without political parties will lose its meaning. Thus, political parties become important instruments in democracy?

An important instrument for political parties in democracy has been set in the particular role given to the party as a forum to bridge the aspirations in distributing and relocating social and political power to the level of the country's political superstructure through some elections. In portraying these functions, political parties are confronted with important tasks that relate to the administration of the state, such as carrying out the function of political aggregation, the function of political aspiration, political education, political recruitment, political mobilization to win election, and set their representatives in the position of governmental politics ${ }^{8}$.

\footnotetext{
${ }^{1}$ www.hukumonline.com, Rules of Party Court Judged Inconsistently, September 10, 2015, Accessed November 9,2018

${ }^{2}$ The constitution according to ECS Wade is, "the text which outlines the main framework and tasks of the governing bodies of a country and determines the main points of work of these bodies."

${ }^{3}$ Roscoe Pound, Scope and Purpose of Sociological Jurisprudence, Harvard: 25 Harvard Law Review, 1912.

${ }^{4}$ Samuel P. Huntington, Political Order In the Midst of Shifts in Mass Interests, Translation of Political Orders in Changing Societies, Interpreting: Sahat Simamora and Suryatim, Jakarta: RajaGrafindo Persada, 2003. p. 472.

${ }^{5}$ Jimly Asshiddiqie, Freedom of Association, Dissolution of Political Parties and the Constitutional Court, Jakarta: MKRI General Secretariat and Registrar, 2006. p. 52

${ }^{6}$ Jimly Asshiddiqie, Introduction to State Law, Jakarta: Raja Grafindo Persada, 2014. Hal. 401-402. Although political parties play an important role in every democratic system, there are also many critical and even skeptical views on political parties. The most serious view among them is that the political party is actually nothing more than a political vehicle for a ruling elite or intending to satisfy the "lust" of his own power. Political parties only function as a tool for a handful of fortunate people who succeed in winning the voice of people who are easily fooled, to impose certain public policies at the expense of the general will

${ }^{7}$ Firdaus,"Implications of the Party System for Government Stability in the Indonesian State Administration System Before and After Amendments to the 1945 Constitution", Dissertation, Bandung: Doctor of Law Program, Padjadjaran University, 2012. p. 35

${ }^{8}$ Ahmad Sukardja, State Administration Law and State Administrative Law in the Siyasah Jurisprudence Perspective, Jakarta: Sinar Grafika, 2012. p. 144
} 
Furthermore, the legal principles of governing the resolution of internal political party disputes that must be obeyed in accordance with Law No. 2/2011 must firstly go through an internal party's forum. In accordance with the Article 32 paragraph 1 of Law No. 2/2011 that political party disputes are resolved by internal political parties as stipulated in the Statutes/Bylaw. The spirit in the Article 32 paragraph 1 is that political parties can solve their own problems, and the rules and procedures for decision making are in the party's Articles of Association (AD) that is to limit, so that not all problems are brought to justice. Besides, in line with the needs of the Indonesian at present time, the normative political party disputes have undergone a change, that is the enactment of Law No. 2 of 2011, so that the life and the political party's dynamics are more harmonious, dynamic, and fair in accordance with Pancasila's values. Based on this law, there is a special court that hands over political party disputes. Firstly, a political party court formed by a political party has the authority to examine and adjudicate political party disputes.

Secondly, the formation of a political party's court is conducted by a political party. The procedure for the formation of a political party's court is regulated in the Article 32 paragraph 3 of Law no. 2/2011 which states that the composition of the political party's court or other designations as referred to paragraph 2 , should be submitted by the leaders of the political party to the ministry. Therefore, the authority of a political party's court judge in adjudicating party disputes is obtained through the authority of a political party, while the judge is the management of a political party. The judges of the court in adjudicating disputes on political parties must obtain this authority from the state represented by the head of state. Third, the trial process in the political party's court is 60 (sixty) days. In accordance with the Article 32 paragraph 4 of Law No. 2/2011, the internal political party disputes as in paragraph 2 must be resolved in no more than 60 days. This Article answers the community's criticism of the slow pace of court's services in resolving cases.

The effectiveness of the government system (effective governance) adopted in a country is measured through the ability of the government to implement a policy through the quality of public services from independence of the political pressures and the quality of public policy formulation between the President and the Parliament and its implementation as well as the government's commitment in implementing policies ${ }^{1}$. In this case, Adrew B. With Ford and Soo Young Lee has asserted:

"Government's effectiveness indicator is to capture the capacity of the state to implement policies by measuring the quality of public services and the degree of independence from political pressures ..."

This means that the government will be effective as long as the government can avoid political pressures that can disrupt the authority and independence of the President in realizing the ideas, vision and mission , and programs of the President. The more the President's autonomy from political pressures, the stronger and more effective is the government ${ }^{3}$. An effective presidential-based government in effective constitutional law is also a stable government without excessive confrontation with the DPR (House of Representatives), but rather a constructive relationship rather than collusive without forgetting the supervisory function as a limitation of the President's power. This method will create a situation where the presidential institution (as well as the authority) can realize political platforms and working programs effectively ${ }^{4}$.

The relationship between the President (executive) and the DPR (legislative); without being collusive, is intended to beable to monitor each other proportionally. Besides, it can also create a balanced relationship between both parties. This model of relationship will produce a "check and balance" mechanism to avoid tyranny between the two parties. In the context of the state administration, the relationship between the President and the parliament, in term of "check and balance" will have a sufficiently strong influence to realize the effectiveness of the government. It means that the more balanced the two relations will be, the more effective the wheels of government will be. On the contrary, the increasingly unequal relation between two institutions above, can increasingly disrupt the effectiveness of the government system that is being adopted.

One of the objectives of the amendments to the 1945 Constitution that has been carried out for 4 (four) times in the period of 1999-2002, is to create a democratic government characterized by a strong and effective government, and to realize the strengthening and effectiveness of government. This is the fundamental reasoning that "check and balance" mechanism is created. By this, the presidential institution and parliamentary institution are more independent and be able to aboid the intervention of other institutions. Each institution is given the authority to do its job, and this mechanism will make state institutions working effectively according to their respective functions ${ }^{5}$.

\footnotetext{
${ }^{1}$ Adrew B. With Ford and Soo Young Lee, The Efficiency of Democracy in Making Government Effective Cross National Evidence, Paper present at the annual meeting of the American Political Science Association, Toronto: Ontario, September, 2008. p. 7

${ }^{3}$ Kacung Marijan, SBY Coalition Building Fragile, Jawa Pos, 4 January 2010, p. 4

${ }^{4}$ Denny Indrayana, 2007. Effective Coalition Building, Not 'Presidential' or 'Presidency' paper presented at the Constitutional Law Expert Meeting with the theme 'Continuing Changes to the 1945 Constitution of the Republic of Indonesia 1945' held by the Center for Constitutional Studies (Pusako) FH Unand in collaboration with the DPR RI in Bukittinggi May 11-13, 2007, p. 8

${ }^{5}$ Sudi Fahmi, 2003, 'Towards a Balance of Relationship between Legislative and Executive Institutions' in Respublika's Legal Journal, No. 4, Vol.2 of 2003. p. 210
} 
In fact, the design of the 1945 amendment conceptually has clearly led to the dominance of the DPR over the President (legislative heavy). The executive power which is originally very strong has been cut down as previously sensed to be executive (executive heavy) has now become legislative (legislatve heavy). The problem faced by the Indonesian is that the results of the amendment that have not only adopted a purely presidential system, but have increasingly strengthened the authority of the DPR through legislative authority. In addition, it has also shifted the power of the President in forming laws, and places the President to have the right to submit a Legal Draft ${ }^{1}$. Indeed, the DPR forms a power to form laws ${ }^{2}$. This provision illustrates the shift in legislative power from the authority of the President. Previously, the President who held the power to form laws with the approval of the Parliament. Contrary at present, the formulation of power has become the authority of the DPR, whereas the President is merely entitled to submit a Legal Draft to the DPR ${ }^{3}$.

Every draft is discussed by the Parliament and the President for mutual agreement. If the draft does not get a mutual agreement, the draft may not be submitted further to the DPR in future times. The draft has been jointly approved by the President with no more than 30 days of its approval, and that the draft has been legally valid and must be enacted. Based on the 1945 Constitution after the amendments and the organic law, the DPR is even granted a single right for itself to select public officials, such as the leader of Indonesia Bank (BI), the Commander of the Armed Forces, the National Police Chief, as well as the leaders and members of the state commission which have been established through the law. This authority should be attached to the President in the presidential system scheme, and it should become an opportunity for the DPR to institutionalize 'interference' with the President. The design of the constitution which is originally intended to balance executive-legislative power has finally been trapped in a situation 'fully loaded with DPR' (DPR heavy). By this, there is an impression that the Indonesian government system (according to the 1945 Constitution after the amendment), is indeed a presidential but parliamentary sense ${ }^{4}$. This fact shows that presidential essence is reduced by parliamentary zeal, so that there is a tendency for the pseudo presidential system and secretly political elites to have carried out this kind of 'parliamentary political convention'.

The parliamentary-sensed presidential system happens due to the design of the 1945 constitution after the amendment has given a very broad and strong role to the DPR, while the President is getting weaker in the scope of the DPR. The weaker position of the President in the viewpoint of the DPR in their working relation, has made the administration run ineffectively, especially if the elected President is not a representation of the majority parties in the DPR. political platforms and their work programs effectively.

Based on the provisions of the Article 32 Law No. 2 of 2011 concerning Amendments to Law No. 2 of 2008 on Political Parties, clearly states procedurally that if the internal disputes occur within a political party, the provisions should have been resolved by the internal party as regulated in the Articles of Association (AD) and Bylaws (ART), while the settlement is submitted to the political Party's Court. The term "Political Party Court" has a different designation in each party, but has the same essence, namely the authority to resolve party disputes internally before being resolved externally. The composition or membership of a political party court or other designation as referred by the leader of a political party to the Ministry of Law and Human Rights (Kemenkum HAM). As written in the provisions of the Article 32 paragraph (3) of Law No. 2 of 2011 on Political Parties which states that: "the composition of the political Party's Court or other designations as referred to paragraph (2) is conveyed by the leadership of the political parties to the Ministry". Indeed, there is no stipulation in the explanation of the Article 32 of Law No. 2 of 2011 on Political Parties concerning the establishment of a political Party's Court, but the membership of a political Party's Court must have neutrality or impartiality towards internal disputes that occur.

The settlement of internal political party's disputes that is resolved through the Political Party's Court must be resolved with no more than 60 (sixty) days. Whereas, the settlement of disputes resolved by the District Court should not be more than 60 (sixty) days after the lawsuit is registered in the District Court secretariat and by the Supreme Court with no more than 30 (thirty) days since the cassation memory is registered in the Supreme Court. Therefore, in the internal dispute over a political party (in accordance with the laws of the political parties in force in Indonesia), this way is to firstly resolve the internal dispute of a political party through the political Party's Court. However, when it is not reached, it can be resolved through the court.

The existence of an internal political party's settlement through a political Party's Court institution can actually be interpreted as an alternative effort to resolve disputes through the party's internal forum before making legal efforts to the court. The alternative to settle disputes is a way to resolve disputes in addition to the way that is generally adopted by the community. The alternative dispute resolution is also called as an alternative solution outside the court, although this program is one alternative mechanism of dispute resolution, namely mediation or

\footnotetext{
${ }^{1}$ Article 5 paragraph (1) of the 1945 Constitution Post Amendment

${ }^{2}$ Article 21 paragraph (-) of the 1945 Constitution Post Amendment

${ }^{3}$ Jimly Asshidiqie, Consolidated Manuscripts of the 1945 Constitution After the Fourth Amendment, Jakarta: PSH Constitutional Law Faculty

of Law, University of Indonesia, 2002. p. 7

${ }^{4}$ Syamsudin Haris, the Presidential-sensed Parliamentary System, Kompas, 28 November 2008. P.6
} 
consensus agreement. Besides, the settlement of internal political party's disputes through a political Party's Court institution is actually a primary choice and as an alternative form of dispute resolution sought by parties in hostile political parties. In the settlement through the political Party's Court, the resolution of a problem can be resolved properly, quickly with relatively affordable cost and has legal force through its decision in the form of an agreement with some certain points.

\subsection{The Concept of Settlement of the Political Party's Management Disputes Based on the Indonesian Democratic System}

The formation of a political Party's Court is a mandate from Law No. 2/2011, where in the Article 32 paragraph 2 describes the settlement of disputes by political parties as referred to paragraph 1 conducted by a political Party's Court or other designation formed by a political party itself. The composition of the the court is conveyed by political parties to the ministry. The article that becomes a legal reference is the legal basis for the formation of a political Party's Court as an institution authorized to invent party's disputes.

The purpose of regulating political party's disputes can be seen from the provisions of governing political party disputes. From various provisions in several countries, one of political party's dispute settlement arrangements is to protect the state's ideology, democracy, rule of law, legal efficiency and certainty, national security, and empowerment of political parties. The legal arrangements for resolving political party's disputes are directed at simplifying litigation procedures and establishing a strong and independent party system. This freedom places political parties initially as individual private organization even though their activities and objectives are public.

The idea of forming a Party's Court in Law No. 2/2011 by the DPR, has been inspired by the internal disputes of the PKB (Partai Kebangkitan Bangsa) that emerges in the legal turmoil is a new history in the law, namely the emergence of political party's disputes law as regulated in the Article 32 and the Article 33 of Law No. 2/2011. The authority of the Court of political parties can be traced through the provisions of Law No. 2/2011 Article 32 paragraph 1 which states that political party's disputes are resolved by internal political parties as stipulated in the Statutes and Bylaw. The Party's Court is given the authority to adjudicate cases of authority abuse performed by the party's administrators. The abuse of authority according to Law No. 30/2014 on Government Administration is regulated in the Article 17 regarding the prohibitions on the abuse of authority. This legal law states that governmental agencies/officials are prohibited from abusing authority. The prohibition of authority abuse includes (a) prohibitions beyond authority; (b) a prohibition on compiling authority; and/or (c) prohibition of arbitrary actions. This abuse of authority is according to the provisions of the Article 32 paragraph 1 of Law No. 2/2011, and is included in the category of political party's disputes which becomes the absolute competence for the Political Party Court.

Correspond to that, the Pancasila's democracy in accordance with the forth precepts states that: "Democracy is led by wisdom in consultation/representation". Critically speaking, when a prolonged impasse occurs and a vote is held, so democracy is not the same as voting. In this case, deliberation is the most elegant and convenient way in solving problems for party's disputes, and all parties have a deliberative forum. As in fact that the Constitution No. 2/2008 or Law No. 2/2011 does not regulate the procedures for deliberations as well as their levels and types. The arrangements regarding the deliberations and the decision-making process within the party carried out by the legislators are left entirely to the political parties that have been regulated in the Article of Association (AD)/Bylaw (ART) on the party's results of the Conference as the highest consultative forum in the party. Therefore, every problem that occurs within the political parties in Indonesia should be responded and completed through party's discussion forum that has been available in all level of structures by relying on the regulations within the party itself.

Similar to this, the arrangement for settlement of political party's disputes in the Article 32 and Article 33 of Law no. 2/2011 with the aim of regulating the pattern of accelerating dispute resolution that is compulsory for political parties to form the Party's Court, has shifted the authority of the court which has the authority to adjudicate political party's disputes. The formation of a political Party's Court is expected to encourage the independence of political parties that can solve their own problems without excessive interference from the Government or the judiciary. This is in accordance with the Article 12 letter (b) of Law No. 2/2008 which states that political parties have the right to regulate and manage the household organization independently.

However, the settlement of party's disputes through the District Court is a last resort if the deliberation and settlement through the Party's Court cannot be reached. The legal basis for bringing such cases in party's dispute resolution to a district court has been clearly clarified in the Article 33 paragraph 1 of Law no. 2/2011 which states that in the event of dispute resolution as referred to the Article 32 which is still not reached, the dispute resolution should be carried out through the District Court. Political party's disputes in the Indonesian National Legal System $(\mathrm{PN})$ are qualified as civil cases and that the trial also uses civil procedural law, but there are some differences in it, namely: first, for political party's disputes filed for settlement through a district court, the trial process is limited to only 60 days as in the Article 33 paragraph 3; second, the District Court's decision on political party's disputes 
is the first and final decision of the Article 33 paragraph 2; third, there is no effort for legal appeal, the PN verdict can only be appealed to the Supreme Court as in the Article 33 paragraph 2; fourth, the cassation examination process in the Supreme Court is only 30 (thirty) days as in the Article 33 paragraph 3.

The lengthy legal process does not also necessarily end the dispute, because after the management of the opponent wins and gets the verdict of party management from the Minister of Law and Human Rights, the decision is sued again to the Civil Court of Justice (PTUN), legal appeal, an appeal to the Judicial Review (PK). Besides, Political Party's dispute settlement arrangements through district courts has conflicted with civil procedural law, because there are only two types of cases for civil lawsuits through district courts, namely unlawful acts (PMH) and doubtful promises, whereas party disputes cases are administrative matters that are not becoming the authority of the District Court to adjudicate. After the reform, the authority of the PN in adjudicating matters has been revoked and has been shifted to newly created-state institution, namely an institution outside the justice system that carries out the judicial function. One of them is that the PN's authority to adjudicate cases of internal political party's disputes that has been revoked based on the provisions of the Article 32 paragraph 2 of Law No. 2/2011. However, the revocation is not absolute, because when the dispute case has been tried and decided by the Party's Court and the parties are not satisfied, so that the case can be re-submitted through PN as stipulated in the Article 33 paragraph 1.

In this regard, the presence of the Party's Court as the executor of judicial power in the field of party's dispute resolution is a necessity to answer based on the timely demands. Therefore, the position of the Party Court as the executor of judicial power must be eventually strengthened both from the institutional and authority aspects. Once, the party's disputes are specific and typical political organization where not everyone can know what is really happening. For this reason, the lawmakers are aware that it is the time to settle political party's disputes fully in the hands of Political Parties without government's interference.

Up to the present time, there has been no regulation regarding the execution of decisions on the Party's Court. Most of which are administrative in nature, so that for the execution of the decision, there is no need for reinforcement. For some cases under the authority of the Political Party's Court can be generally classified into 2 (two) sections, namely: first, cases that concerns with the rights of party's members who are usually associated with termination for the interests of Interim Replacement (PAW) members of the DPR/DPR-D. Second, cases that are related to the management of Political Parties. This Political Party's decree on the management of Political Parties is disputed when it relates to: first, the registration of the Candidates for President/Vice President in the Election of President and Vice President both as bearers and supporters. Second, the registration of candidates for governor/deputy governor in regional elections for governor/deputy governor both as bearers and supporters. Third, the registration of candidates for regent/deputy regent, mayor/deputy mayor in the election of regent/city and or/ regional head for both bearers and supporters. Fourth, the registration of legislative candidates for DPR/DPRD in legislative elections.

For party's management of cases, the Party Court's decision is used by the Indonesia General Election Commission (KPU) to find out which management has the right to nominate the candidates for president, governors, regents/mayors and is also used by the police for securing Political Party's events, the Ministry of Internal Affairs and Regional Governments to disburse funding assistance from Political Parties, the Ministry of Law and Human Rights (Menkum \& HAM) for authorization of party's management, the President, KPU, the Chairman of the DPR, and finally for the Governor to process PAW's applications for the DPR/DPRD members. Thus, it is clear that the Party Court's decision is not only applied to internal Political Parties, but also to external Political Parties.

In legal terms, each decision must be considered correctly before there is a cancellation by a higher court; the principle of res judicata pro veritate habetur. This provision is intended to guarantee legal certainty. As for legal remedies or resistance that can be carried out by parties who are dissatisfied with the Party Court's decision can be done through Judicial Review (PK) which becomes an extraordinary legal remedy where the PK's legal remedy can only be filed against a court decision that has permanent legal force. Although the Article 32 paragraph 5 of Law No. 2/2011, that the court's decision is final and binding, the PK legal efforts should remain opened. This is in the context of respect for human rights as has been stipulated in the Constitution.

\section{Conclusion}

Based on the description above, it can be concluded that the disputes regarding the management of Political Parties in Indonesia based on Law Number 2 of 2008 concerning Political Parties are internal disputes between political parties. Every political party has an internal institutional mechanism in managing various problems and disputes that arise. The mechanism is designed to build party's autonomy in handling and solving various problems as a basic principle of democracy, eventhough it is not uncommon to face an undemocratic internal mechanism. Accessing to justice among party's members occasionaly faces a deadlock between the will of the majority or even a minority of functionaries in the party's management structure that forces their will against the aspirations of the majority which can lead to strife and disunity. 
On the other hand, the settlement of Political Party's management disputes generally applies two systems of dispute resolution available, namely by using the adjudication channels (court and arbitration) or known as "litigation" and using the non-court or non-adjudication route. Meanwhile, the adjudicative dispute resolution can be divided into two kinds, namely public adjudicative and private adjudicative. Public adjudication is carried out through state court institutions (formal litigation).

Finally, the concept of resolving disputes over Political Party's management according to the Indonesian democratic system based on the provisions of law Number 2 of 2011 is: first, there needs to go through an internal party's forum. The stipulation is intended, so that Political Parties can solve their own problems. However, the rules and procedures for decision making are in the basic rules of the party's household to limit in order that not all problems are brought to justice. Second, the formation of a Political Party's Court by a political party. Third, the trial process in the Party's Court is 60 (sixty) days length. Hence, in accordance with the Article 32 paragraph 4 of Law No. 2/2011 which states that the internal Political Party's disputes as referred to paragraph 2 must be resolved is no more than 60 days.

\section{Suggestion}

Based on the analysis, the authors provide the following recommendations:

1. For the Party's Court; there needs to be an overhaul on the composition of the Party's Court which has been more dominated by the concerned Party, so that there is a need for structural changes where Party's Court members must involve outside members, judges and independent professional individuals outside the Party. This is supposed to achieve the objective results of decisions.

2. For Political Parties; there needs to be a clear, certain and confidential mechanism regarding the settlement of internal Party's disputes; bearing in mind that the development of democracy has increased the political participation of the community in the life of the state. The increase in participation is in line with people's political awareness which is getting better and smarter to use their political rights. Party's disputes that are overly disclosed will affect the level of vigilance and trust in the concerned Political Party to reduce the level of trust of the community which then also affects the electability of the Political Party.

\section{References}

A'an Efendi, 2015, Penyelesaian Sengketa Lingkungan Melalui Gugatan Administratif di Peradilan Tata Usaha Negara, Airlangga University Press, Surabaya

A'an Efendi, Freddy Poernomo, IG. NG Indra S Ranuh, 2016, Teori Hukum, Jakarta, Sinar Grafika.

Abdul Mukthtie Fadjar, 2013, Prolog "Perjuangan Untuk Sebuah Negara Hukum yang Bermartabat", dalam Membangun Negara Hukum yang Bermartabat, Tim Penulis (Prof. Dr. Hariyono dkk.), Malang, Setara Press.

Adi Sujatno, 2009, Moral dan Etika Kepemimpinan Merupakan Landasan ke ArahKepemimpinan yang Baik (Good Government), Team 4 AS, Jakarta

Ahmad Suhelmi, 2007, Pemikiran Politik Barat; Kajian Sejarah Perkembangan Pemikiran Negara, Masyarakat dan kekuasaaan, PT Gramedia Pustaka, Jakarta.

Amiruddin dan Zainal Asikin, 2012, Pengantar Metode Penelitian Hukum, Penerbit Rajawali Pers, Jakarta.

Ateng Syafrudin, Jurnal Pro Justisia, "Menuju Penyelenggaraan Pemerintahan Negara yang Bersih dan Bertanggung Jawab”, Edisi IV, Universitas Parahyangan, Bandung, halaman 22. 2013;

Cherif Bassiouni, 1998 Toward a Universal Declaration on The Basic Principles of Democracy : From Principles to Realisation, The Inter-Parliementary Union, Geneva, Switzerland.

David Beetham, 1998, Democracry: Key Principle, Institutions and Problems, The Inter-Parliementary Union, Geneva, Switzerland.

Dede Rosyada, dkk., 2003, (Pendidikan Kewargaan Civic Education) Demokrasi, Hak Asasi Manusia \& Masyarakat Madani, Abdul Rozak dkk., ICCE UIN Syarif Hidayatullah Jakarta kerjasama The Asia Foundation \& Pernada Media, Jakarta;

Dedi Ismatullah dan Asep A. Sahid Gatra, 2007, Ilmu Negara Dalam Multi Perspektif. Pustaka Setia, Bandung.

Dyah Ochtorina, Dewi Astuty Mochtar, 2012, Pengantar Ilmu Hukum, Malang, Bayumedia Publising.

Elly M. Setiadi dan Usman Kolip, 2011, Pengantar Sosiologi Pemahaman Fakta dan Gejala Permasalahan Sosial. Teori, Aplikasi, dan Pemecahannya, Kencana Prenada Group, Jakarta;

F. Budi Hardiman, 2009, Demokrasi Deliberatif, Kanisius, Yogyakarta

George Sorensen, 2003, Demokrasi dan Demokratisasi: Proses dan Prospek dalam Sebuah Dunia yang Sedang Berubah. Penerjemah I Made Krisna, Tadjuddin Noer Effendi, Pustaka Pelajar, Yogyakarta;

Harold J. Laski, 1951, A Grammar of Politic, Eleventh Impression, George Allen \& Unwin Ltd, London;

Irving M. Zeitlin, 199, Memahami Kembai Sosiologi, Gajah Mada University Press, Yogyakarta;

J. Dwi Narwoko dan Bagong Suyanto, 2005, Sosiologi Teks Pengantar dan Terapan, Kencana Prenada Media Group, Jakarta;

Jimly Asshiddiqie, 1997, Gagasan Kedaulatan Rakyat dalam Konstitusi dan Pelaksanaannya di Indonesia, Ichtiar 
Baru-van Hoeve, Jakarta;

Jimly Asshiddiqie, 2006, Kemerdekaan Berserikat Pembubaran Partai Poltik dan Mahkamah Konstitusi, Sekretariat Jenderal dan Kepeniteraan Mahkamah Konsitusi RI, Jakarta;

Johnny Ibrahim, 2012, Teori dan Metodologi Penelitian Hukum Normatif, Cetakan Keenam, Penerbit Bayumedia Publishing, Malang;

Kamus Besar Bahasa Indonesia, Jakarta. Balai Pustaka, 2005

M. Fadjroel Rachman, 2007, Merintis Jalan Demokrasi ke Sosialisme Partisipatif, dalam M. Fadjroel Rachman dan Taufiqurrahman, ed., Demokrasi Tanpa Kaum Demokrat: Tentang Kebebasan, Demokrasi, dan Negara Kesejahteraan, Depok, Jakarta;

M. Hadin Muhjad dan Nunuk Kuswardani, 2012, Penelitian Hukum Indonesia Kontemporer, Penerbit Genta Publishing, Yogyakarta;

M. Zaki Mubarak, Demokrasi dan Kediktatoran: Sketsa Pasang Surut Demokrasi di Indonesia", Jurnal Politika: Jurnal Pencerahan Politik Untuk Demokrasi III, no 3 (Desember), 71. 2007;

M.R Khairul Muluk, 2006, Desentralisasi dan Pemerintahan Daerah, Bayu Media Publishing, Malang;

Masykuri Abdillah, 1999, Demokasi di Persimpangan Makna; Respon Intelektual Muslim Indonesia terhadap konsep Demokrasi 1966-1930, Tiara Wacana, Yogyakarta;

Moshe Maor, 1997, Political Parties and Party Systems, Routlegde II New Fetter Lane, London

Munir Fuady, 2010, Konsep Negara Demokrasi, Refika Aditama, Bandung;

Munir Fuady, 2013, Teori-teori Besar (Grand Theory) dalam Hukum, Kencana Prenada Meda Group, Jakarta;

Peter Mahmud Marzuki, 2005, Penelitian Hukum, Edisi Revisi, Penerbit Kencana Prenada Media Group, Jakarta;

Philippus M. Hardjon., Jurnal Pro Justisia, "Tentang Wewenang Pemerintahan (Berstuurbevoegdheid)", Tahun XVI Nomor 1, Januari 1998

Ridwan H.R., 2008, Hukum Administrasi Negara, Penerbit PT Raja Grafindo Persada, Jakarta;

Robert lawang, 1994, Buku Materi Pokok Pengantar Sosiologi, Universitas Terbuka, Jakarta;

Roscoe Pround, 1957, The Development of Constitutional Guarantees of Liberty, Yale University Press, New Heaven London;

Siti Sundari Rangkuti dalam Yuliandri, Membentuk Undang-undang yang berkelanjutan, Editor Radian Salman, dkk, 2008, Dinamika Perkembangan Hukum Tata Negara dan Hukum Lingkungan, Edisi khusus Kumpulan Tulisan dalam Rangka Purnabakti Siti Sundari Rangkuti, Airlangga University Press, Surabaya;

Soedikno Mertokusumo, 2011, Teori Hukum, Universitas Atma Jaya, Yogyakarta;

Soerjono Soekanto dan Sri Mamudji 2011, Penelitian Hukum Normatif, Penerbit Rajawali Pers, Jakarta;

Thomas Meyer, 2003, Demokrasi Sebuah Pengantar Untuk Penerapan, Friedrich-Erbert-Stiftung, Jakarta;

Thomas Poguntke and Paul Webb, 2005, The Presidentialization of Politics in Democratic Societies : Framework for Analisys, The Presidentialization of Politics, a Comparative Study of Modern Democratic, Oxford, University Press, England; 